\title{
Relationship of lymphovascular invasion with lymph node metastasis and prognosis in superficial esophageal carcinoma: systematic review and meta-analysis
}

\author{
Jinxin Yang ${ }^{1 \dagger}$, Zhouyi Lu ${ }^{2+}$, Lintao $\mathrm{Li}^{1}$, Yong Li ${ }^{1}$, Yulong Tan², Dekang Zhang ${ }^{1 *}$ and An Wang ${ }^{2^{*}}$
}

\begin{abstract}
Background: The development of tumor cells inside the lymphatics or blood vessels is known as lymphovascular invasion (LVI). The correlation between LVI, lymph node metastasis (LNM), and the diagnosis of superficial esophageal carcinoma (SEC) remains unclear.

Methods: We searched Embase, PubMed, Web of Science, and Cochrane Library databases for prospective articles to better understand the relationship between LVI, LNM, and SEC diagnosis.

Results: We included 23 articles containing data for 4749 patients (range: 54-598) in our meta-analysis. The hazard ratio between $L V I$ and overall survival (OS) was 1.85 with $95 \%$ confidence interval $(C I)(1.10-3.11, P=0.02)$. LNM rate was higher in SEC patients with LVI than SEC patients without LVI (univariate: OR $=4.94,95 \%$ Cl: 3.74-6.53, $P<$ 0.0001; multivariate: $\mathrm{OR}=5.72,95 \% \mathrm{Cl}: 4.38-7.4, P<0.0001)$. No obvious publication was found.
\end{abstract}

Conclusions: The results indicate that LVI plays a dominant role in the prognosis of LNM in SEC and in the prognostic prediction for SEC.

Keywords: Lymphovascular invasion, Lymph node metastasis, Prognosis, Superficial esophageal carcinoma

\section{Background}

Superficial esophageal carcinoma (SEC) can be classified as submucosal (T1b), mucosal (T1a), or intraepithelial (Tis) irrespective of lymph node metastasis (LNM). Patients suffering from SEC have a better chance of survival after esophagectomy compared to those with advanced esophageal carcinoma (EC). According to the Japanese criteria, the depth of tumor invasion is subclassified into six layers. The mucosa is subdivided into the

\footnotetext{
*Correspondence: zhangdkscch@126.com; wangantxwd@163.com

${ }^{\dagger}$ Jinxin Yang and Zhouyi Lu contributed equally to this work.

'Department of Radiation Oncology, Sichuan Cancer Hospital and Institute,

'Department of Radiation Oncology, Sichuan Cancer Hospital and Institute,
Sichuan Cancer Center, School of Medicine, University of Electronic Science and Technology of China, Chengdu, Sichuan, China

2Department of Thoracic Surgery, Huashan Hospital, Fudan University, Shanghai, China
}

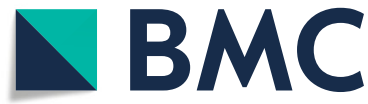

(c) The Author(s). 2020 Open Access This article is licensed under a Creative Commons Attribution 4.0 International License, which permits use, sharing, adaptation, distribution and reproduction in any medium or format, as long as you give appropriate credit to the original author(s) and the source, provide a link to the Creative Commons licence, and indicate if changes were made. The images or other third party material in this article are included in the article's Creative Commons licence, unless indicated otherwise in a credit line to the material. If material is not included in the article's Creative Commons licence and your intended use is not permitted by statutory regulation or exceeds the permitted use, you will need to obtain permission directly from the copyright holder. To view a copy of this licence, visit http://creativecommons.org/licenses/by/4.0/. The Creative Commons Public Domain Dedication waiver (http//creativecommons.org/publicdomain/zero/1.0/) applies to the data made available in this article, unless otherwise stated in a credit line to the data.

intraepithelial (m1) region, lamina propria (m2), and muscularis mucosa $(\mathrm{m} 3)$ while the submucosa is homogeneously classified into three sections: inner (sm1), middle (sm2), and deep submucosa (sm3) [1]. The prognostic factors for EC include the histology type, tumor size, grade category, invasion depth, blood vessel and lymphatic vessel permeation, as well as LNM and distant metastasis [2]. EC patients with LNM frequently have an adverse prognosis. Therefore, the impact of LVI on LNM and prognosis requires attention.

The development of tumor cells inside the lymphatics or blood vessels is known as lymphovascular invasion (LVI). Lymphatic vessels are believed to play a crucial role in LNM and their presence increases the micrometastatic risk in locoregional malignancy [3]. Though 
lymph node metastasis via LVI or lymphatic vessels has not been confirmed [4], lymphatic vessels are known to provide entry for the penetration of tumor cells [5]. Some studies have provided evidence of an association between LVI and LNM in SEC. Nonetheless, the impact of LVI on OS and LNM in SEC requires investigation. Thus, we conducted a meta-analysis to obtain additional insight into the correlation between LVI, LNM, and prognosis in SEC.

\section{Methods}

\section{Search strategy}

We searched the Embase, PubMed, Web of Science, and Cochrane Library databases for prospective articles. The search terms used were (lymphovascular invasion (LVI) OR lymph vessel invasion OR angiolymphatic invasion OR lymphatic invasion) AND (superficial esophageal cancer (SEC) OR submucosal esophageal carcinoma OR mucosal esophageal cancer OR T1 esophageal carcinoma). We conducted a manual search of the results to identify the prospective studies relevant to our investigation. We then performed preliminary screening by checking the titles followed by the abstracts. Relevant studies were confirmed after reviewing the full text. In the present study, we regarded lymphatic invasion as LVI.

\section{Exclusion and inclusion criteria}

Studies were considered eligible based on the following criteria: (1) SEC; (2) hazard ratio (HR) for prognosis and odds ratio (OR) for LNM; (3) papers published in English; (4) the latest or most relevant articles published by the same group/author.

The exclusion criteria were as follows: (1) duplicate conference papers, reviews, reports, abstracts, and letters; (2) studies about other cancer types, animal models, esophageal cancer cell lines, and treatment methods; (3) lack of data on prognosis or LNM; (4) studies published in languages other than English; (5) esophagogastric junction cancer (EJC).

\section{Preliminary review of studies and quality assessment} Each selected article was reviewed by two independent authors based on the exclusion and inclusion criteria above. When a discrepancy arose, a third author was involved to resolve the differences. Quality assessment was performed using the Newcastle-Ottawa Scale (NOS) [6] and all articles included scored a minimum of five points on the NOS. Researches about prognosis were assessed by critical appraisal of prognostic studies (https://www. cebm.net/wp-content/uploads/2018/11/Prognosis.pdf).

The detailed quality assessment of these studies was displayed in a Table 1 .

\section{Data extraction}

Two independent authors collected data from the studies. The following information was extracted: surname of the first author, follow-up years, region, sample size for the research, treatment characteristics, histology type, depth of invasion, staining methods, the percentage of patients with LVI, information about OS, and LNM and NOS scores. All of the collected information is listed in Table 2. Discrepancies among authors were resolved.

\section{Statistical analysis}

We investigated the correlation between LVI, prognosis, and LNM in SEC patients. HR and OR were effective for the prognosis and LNM with 95\% CI individually. Worse prognosis for SEC was indicated by an $\mathrm{HR}$ value $>1$. Cochrane's Q test (Chi-squared test; Chi2) and the $\mathrm{I}^{2}$ metric were used to test the heterogeneity of the pooled results. $\mathrm{I}^{2}<25 \%$ indicated no heterogeneity; $\mathrm{I}^{2}=25-50 \%$, moderate heterogeneity; $\mathrm{I}^{2}=50-75 \%$, medium heterogeneity; and $\mathrm{I}^{2}>75 \%$, extreme heterogeneity. We used a fixed-effect model (the Mantele Haenszel method) for $\mathrm{I}^{2}<50 \%$ with $P>0.05$ in this meta-analysis. If not, a random-effect model was appropriate for our analysis. We used meta regression and subgroup analysis to explore heterogeneity when necessary [18]. Begg's test was used to assess publication bias. Two-tailed tests were used to calculate the $P$ value and $P \leq 0.05$ was considered statistically significant. Statistical analysis was performed using the Stata/SE version 12.0 for Windows (Stata Corporation, College Station, TX, USA).

Table 1 The detailed quality assessment of prognostic studies

\begin{tabular}{|c|c|c|c|c|c|c|c|}
\hline Author & $\begin{array}{l}\text { Years } \\
\text { Included }\end{array}$ & Region & $\begin{array}{l}\text { Comment } \\
1\end{array}$ & $\begin{array}{l}\text { Comment } \\
2\end{array}$ & $\begin{array}{l}\text { Comment } \\
3\end{array}$ & $\begin{array}{l}\text { Comment } \\
4\end{array}$ & What are the results \\
\hline Leggett (2015) [7] & $1995-2011$ & USA & Yes & Yes & Yes & Yes & $\begin{array}{l}\text { Survival curve, } \mathrm{Cl} \text { is narrow, conclusion is } \\
\text { promotable }\end{array}$ \\
\hline $\begin{array}{l}\text { Yamashina (2013) } \\
\text { [8] }\end{array}$ & $1995-2010$ & Japan & Yes & Yes & Yes & Yes & $\mathrm{Cl}$ is relative marrow, conclusion is promotable \\
\hline Tanaka (2014) [9] & $1988-2010$ & Japan & Yes & Yes & Yes & Yes & $\mathrm{Cl}$ is narrow, conclusion is promotable \\
\hline Xue (2018) [10] & $1990-2004$ & China & Yes & Yes & Yes & Yes & $\begin{array}{l}\mathrm{Cl} \text { is relative marrow, conclusion is relative } \\
\text { promotable }\end{array}$ \\
\hline
\end{tabular}


Table 2 Characteristics of studies included in out meta-analysis

\begin{tabular}{|c|c|c|c|c|c|c|c|c|c|c|}
\hline Author & $\begin{array}{l}\text { Years } \\
\text { Included }\end{array}$ & Region & No. & Treatment Characteristic & Pathology & $\begin{array}{l}\text { Depth } \\
\text { of } \\
\text { Invasion }\end{array}$ & Staining & $\begin{array}{l}\text { Indicator } \\
\text { (No.) }\end{array}$ & $\begin{array}{l}\text { Including } \\
\text { Statistics }\end{array}$ & $\begin{array}{l}\text { NOS } \\
\text { Scores }\end{array}$ \\
\hline $\begin{array}{l}\text { Jia (2016) } \\
{[11]}\end{array}$ & $\begin{array}{l}2010- \\
2015\end{array}$ & China & 93 & Esophagectomy and lymphadenectomy & $\begin{array}{l}\text { SCC/ } \\
\text { Others }\end{array}$ & M1-SM3 & NM & $\operatorname{LVI}(28)$ & LNM & 5 \\
\hline $\begin{array}{l}\text { Sepesi } \\
\text { (2010) [12] }\end{array}$ & $\begin{array}{l}2000- \\
2008\end{array}$ & USA & 54 & Esophagectomy and lymphadenectomy & $A D$ & SM & NM & $\operatorname{LVI}(7)$ & LNM & 5 \\
\hline $\begin{array}{l}\text { Leggett } \\
\text { (2015) [7] }\end{array}$ & $\begin{array}{l}1995- \\
2011\end{array}$ & USA & 269 & EMR followed by ablative techniques & $A D$ & LP-SM & $\mathrm{H} \& \mathrm{E}$ & LVI(53) & OS & 6 \\
\hline $\begin{array}{l}\text { Huh }(2017) \\
{[13]}\end{array}$ & $\begin{array}{l}1996- \\
2015\end{array}$ & Korea & 275 & $\begin{array}{l}187 \text { Esophagectomy and } 88 \text { ER } \\
\text { (Esophagectomy or ER) }\end{array}$ & SCC & M-SM & $\mathrm{H} \& \mathrm{E}$ & LVI(36) & LNM & 6 \\
\hline $\begin{array}{l}\text { Zhou } \\
\text { (2016) [14] }\end{array}$ & $\begin{array}{l}2008- \\
2015\end{array}$ & China & 498 & Esophagectomy with lymphadenectomy & SCC & M1-SM3 & $\begin{array}{l}\mathrm{H} \& \mathrm{E} / \\
\mathrm{IHC}\end{array}$ & $\begin{array}{l}\text { LI(16/ } \\
412)\end{array}$ & LNM & 7 \\
\hline $\begin{array}{l}\text { Moon } \\
(2014)[15]\end{array}$ & $\begin{array}{l}2009- \\
2012\end{array}$ & Korea & 104 & Esophagectomy with lymphadenectomy & SCC & M1-SM3 & $H \& E$ & LVI(13) & LNM & 6 \\
\hline $\begin{array}{l}\text { Mitobe } \\
\text { (2013) [16] }\end{array}$ & $\begin{array}{l}1990- \\
2009\end{array}$ & Japan & 110 & $\begin{array}{l}106 \text { Esophagectomy with lymphadenectomy, } \\
4 \text { esophagectomy follwed ER and } \\
\text { lymphadenectomy }\end{array}$ & SCC & LP-SM3 & $\mathrm{IHC}$ & LI(42) & LNM & 6 \\
\hline $\begin{array}{l}\text { Nentwich } \\
\text { (2014) [17] }\end{array}$ & $\begin{array}{l}1994- \\
2009\end{array}$ & Germany & 67 & Esophagectomy & SCC/AD & SM & NM & $\operatorname{LI}(16 / 61)$ & LNM & 5 \\
\hline $\begin{array}{l}\text { Raja (2011) } \\
{[18]}\end{array}$ & $\begin{array}{l}1983- \\
2010\end{array}$ & USA & 120 & Esophagectomy & SCC/AD & SM & NM & $\operatorname{LVI}(26)$ & LNM/OS & 5 \\
\hline $\begin{array}{l}\text { Nakajima } \\
(2002)[19]\end{array}$ & $\begin{array}{l}1985- \\
1995\end{array}$ & Japan & 84 & Esophagectomy with lymphadenectomy & SCC & SM & $\mathrm{IHC}$ & LI(60) & LNM & 6 \\
\hline $\begin{array}{l}\text { Choi (2011) } \\
{[20]}\end{array}$ & $\begin{array}{l}1991- \\
2009\end{array}$ & Korea & 190 & Esophagectomy with lymphadenectomy & SCC & M1-SM3 & $H \& E$ & LVI(39) & LNM & 7 \\
\hline $\begin{array}{l}\text { Tajima } \\
\text { (2000) [21] }\end{array}$ & $\begin{array}{l}1968- \\
1996\end{array}$ & Japan & 240 & Esophagectomy with lymphadenectomy & SCC & LP-SM & $\mathrm{H} \& \mathrm{E}$ & $\begin{array}{l}\mathrm{LI}(39 / \\
186)\end{array}$ & LNM & 6 \\
\hline $\begin{array}{l}\text { Chiba } \\
\text { (2010) [22] }\end{array}$ & $\begin{array}{l}1992- \\
2008\end{array}$ & Japan & 110 & $\begin{array}{l}107 \text { underwent esophagectomy, } 3 \text { patients } \\
\text { underwent ER followed esophagectomy }\end{array}$ & SCC & M-SM & $\mathrm{IHC}$ & LI(46) & LNM & 6 \\
\hline $\begin{array}{l}\text { Yamashina } \\
\text { (2013) [8] }\end{array}$ & $\begin{array}{l}1995- \\
2010\end{array}$ & Japan & 402 & $\begin{array}{l}\text { EMR or ESD, some patients received surgery } \\
\text { after ER }\end{array}$ & SCC & EP-SM2 & NM & LVI(33) & OS & 5 \\
\hline $\begin{array}{l}\text { Xue (2012) } \\
{[23]}\end{array}$ & $\begin{array}{l}1990- \\
2004\end{array}$ & China & 271 & Esophagectomy & SCC & M2-SM3 & $\mathrm{IHC}$ & LI(51) & LNM & 7 \\
\hline $\begin{array}{l}\text { Ancona } \\
\text { (2008) [24] }\end{array}$ & $\begin{array}{l}1980- \\
2006\end{array}$ & Italy & 98 & Esophagectomy with lymphadenectomy & SCC/AD & M1-SM3 & NM & LI(34) & LNM & 5 \\
\hline $\begin{array}{l}\operatorname{Li}(2013) \\
{[25]}\end{array}$ & $\begin{array}{l}2006- \\
2011\end{array}$ & China & 189 & Esophagectomy with lymphadenectomy & SCC & M1-SM3 & NM & $\operatorname{LVI}(22)$ & LNM & 5 \\
\hline $\begin{array}{l}\text { Qi (2016) } \\
{[26]}\end{array}$ & $\begin{array}{l}2009- \\
2014\end{array}$ & China & 258 & Esophagectomy with lymphadenectomy & SCC & SM & $\mathrm{H} \& \mathrm{E}$ & $\operatorname{LVI}(18)$ & LNM/OS & 6 \\
\hline $\begin{array}{l}\text { Wang } \\
\text { (2016) [27] }\end{array}$ & $\begin{array}{l}2002- \\
2014\end{array}$ & Japan & 598 & Esophagectomy with lymphadenectomy & SCC & M-SM & $\begin{array}{l}\mathrm{H} \& \mathrm{E} / \\
\mathrm{IHC}\end{array}$ & $\begin{array}{l}\mathrm{LI}(62 / \\
228)\end{array}$ & LNM & 6 \\
\hline $\begin{array}{l}\text { Kim }(2008) \\
{[28]}\end{array}$ & $\begin{array}{l}1994- \\
2006\end{array}$ & Korea & 200 & Esophagectomy with lymphadenectomy & SCC/AD & M-SM & NM & LI(33) & LNM & 5 \\
\hline $\begin{array}{l}\text { Tanaka } \\
\text { (2014) [9] }\end{array}$ & $\begin{array}{l}1988- \\
2010\end{array}$ & Japan & 145 & Esophagectomy with lymphadenectomy & SCC & $\begin{array}{l}\text { SM1- } \\
\text { SM3 }\end{array}$ & NM & LVI(84) & OS & 5 \\
\hline $\begin{array}{l}\text { Zhuge } \\
\text { (2018) [29] }\end{array}$ & $\begin{array}{l}2006- \\
2016\end{array}$ & China & 175 & Esophagectomy with lymphadenectomy & SCC & $\begin{array}{l}\text { SM1- } \\
\text { SM3 }\end{array}$ & NM & $\operatorname{LVI}(32)$ & LNM & 6 \\
\hline $\begin{array}{l}\text { Xue (2018) } \\
{[10]}\end{array}$ & $\begin{array}{l}1990- \\
2004\end{array}$ & China & 199 & Esophagectomy with lymphadenectomy & SCC & M2-SM3 & $\mathrm{IHC}$ & $\operatorname{LVI}(27)$ & OS & 6 \\
\hline
\end{tabular}

LVI Lymphovascular Invasion, LI Lymphatic invasion

$E R$ Endoscopic resection, EMR Endoscopic mucosal resection, ESD Endoscopic submucosal dissection

SCC Squamous cell carcinoma, $A D$ Adenocarcinoma, OS Overall survival

EP Epithelium, M Mucosa, SM Submucosa, LP Lamina propria, NM Not mentioned

H\&E Hematoxylin-eosin, IHC Immunohistochemical 


\section{Results}

\section{Characteristics of studies}

We retrieved 603 articles after removing duplicates but excluded 487 articles that were either case reports or only abstracts. A few of the excluded articles were review articles and others contained information about other cancer conditions. Articles published in languages other than English were also excluded. We identified 116 potential articles for full-text review. We excluded 93 articles for the following reasons: 25 were about EJC; 67 lacked data relevant to LVI, prognosis, or LNM; and retrieval of the full text was not possible for six articles; one was excluded due to the same author and institution. The remaining 23 articles, which included information for 4749 patients (range: 54-598), were included in the meta-analysis (Fig. 1). Table 2 shows detailed information about the studies. All studies included in this meta-analysis were rated with a minimum of five stars based on the NOS.

Six studies provided survival information between LVI and prognosis. Two studies reported the association between LVI and prognosis with univariate Cox proportional hazards analysis in included studies $[18,26]$. Four of included studies suggested the association between LVI and prognosis was not significant in SEC patients [8, 9, 18, 26]. The rest two studies showed LVI was a poor prognostic indicator in SEC patients [7, 10].

Sixteen studies provided information on LVI from multivariate analysis of LNM cases. Eight studies provided information on LVI from univariate analysis. One study using univariate analysis reported a $p$ value of 0.049 [12].

\section{LVI impact on OS}

2We included 4 eligible studies containing 1005 patients from multivariate analysis in our meta-analysis. The pooled HR was 1.85 with $95 \%$ CI $(1.10-3.11, P=0.02)$ and the pooled OS showed medium heterogeneity based on random effect model $\left(\mathrm{I}^{2}=54.6 \%, P=0.085\right.$, Fig. 2$)$.

\section{Association between LVI and LNM}

The pooled results showed that patients in the LNMpositive group had an advanced LVI detection rate $(\mathrm{OR}=4.94$, 95\% CI: 3.74-6.53, $P<0.0001$, Fig. 3$)$ in univariate analysis. The combined results exhibited no heterogeneity $\left(\mathrm{I}^{2}=0.9 \%, P=0.422\right)$. The pooled results from 20 studies in multivariate analysis suggested that LVI significantly increased the risk for LNM (OR $=5.72,95 \%$ CI: 4.38-7.48, $P<0.0001$, Fig. 4) with no heterogeneity $\left(\mathrm{I}^{2}=0 \%, P=0.926\right)$.

\section{Publication bias of included studiessl}

There was no evidence of publication bias for OS as demonstrated by Begg's test $(P=1)$ or for LNM (multivariate: $P=0.961$; univariate: $P=0.805)$. The funnel plots were displayed in Fig. 5.

\section{Discussion}

Our study demonstrated that SEC patients with LVI have a poor $\mathrm{OS}(\mathrm{HR}=1.85,95 \% \mathrm{CI}: 1.10-3.11, P=0.02$; $\left.\mathrm{I}^{2}=54.6 \%, P=0.085\right)$. LVI significantly reduces OS in patients with SEC. This conclusion should be clarified with caution due to medium heterogeneity. Additionally, LVI and LNM are strongly correlated (univariate: OR = 4.94, 95\% CI: 3.74-6.53, $P<0.0001, \mathrm{I}^{2}=0.9 \%, P=0.422$; multivariate: $\mathrm{OR}=5.72,95 \% \mathrm{CI}: 4.38-7.4, \quad P<0.0001$; $\left.\mathrm{I}^{2}=0 \%, P=0.926\right)$ in patients suffering from SEC. These results suggest that LVI is an important prognostic factor for patients with SEC with regard to predicting LNM and survival.

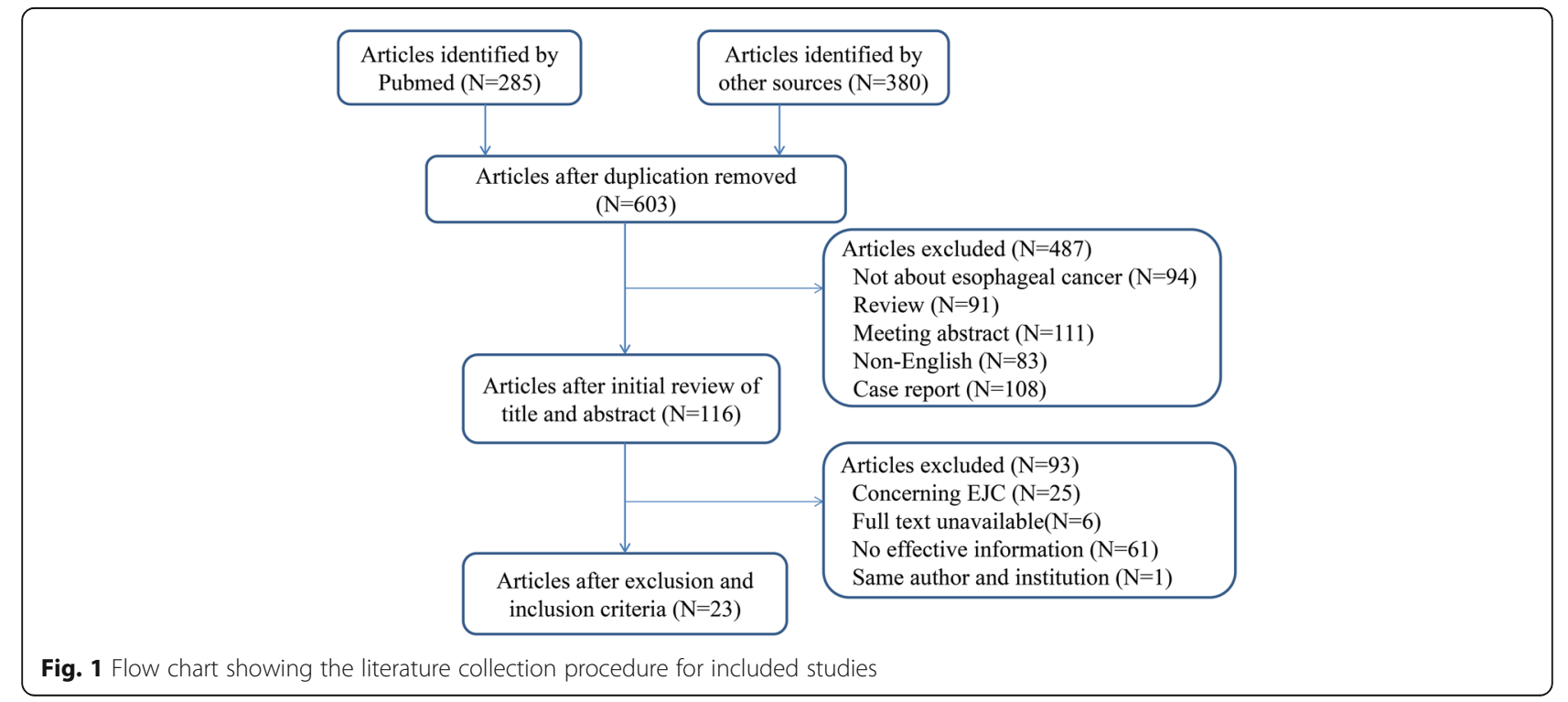




\begin{tabular}{|c|c|c|}
\hline Author & Year & $\mathrm{HR}(95 \% \mathrm{Cl})$ \\
\hline Leggett & (2015) & $1.95(1.18,3.22)$ \\
\hline Yamashina & (2013) & $1.30(0.30,5.63)$ \\
\hline Tanaka & $(2014)$ & $1.09(0.59,2.02)$ \\
\hline Xue & $(2018)$ & $3.42(1.80,6.50)$ \\
\hline \multicolumn{2}{|c|}{ Overall $(I$-squared $=54.6 \%, p=0.085)$} & $1.85(1.10,3.11)$ \\
\hline \multicolumn{2}{|c|}{ NOTE: Weights are from random effects analysis } & \\
\hline & .154 & \\
\hline
\end{tabular}

Fig. 2 Forrest plot showing pooled HR for OS in patients with LVI

SEC is similar to the esophageal tumors, which are limited to the mucosal layer (T1, T0) and include highgrade dysplasia, intramucosal cancer (T1a), and tumors infiltrating the submucosa (T1b) [30]. .Reports state that patients with T0 ( $0 \%$ chance) or T1a (1-2\% chance) esophageal cancer have a minimal risk of local LNM [31]. There is no specific standard available for the detection of LVI. However, the identification of tumor cells in the lymphatic vessels, arteries, or veins during pathological evaluation of specimens indicates LVI. The condition is an independent prognostic factor of LNM in malignant tumors causing lung, prostate, breast, and esophageal cancer. However, the role of LVI in SEC has not been clarified to date. Additionally, the impact of LVI in SEC on OS and LNM has not been assessed using meta-analysis in the past. Therefore, we conducted this study by analyzing data for 4854 patients reported in 24 eligible articles retrieved from PubMed and other relevant sources. We demonstrated LVI relevance in LNM and the prognosis for patients with SEC. According to a literature review, our work is the first systematic review and meta-analysis on LVI relevance in LNM and prognosis in patients with SEC.

During the early stage of esophageal cancer, LVI is regarded as a potential prognostic factor in predicting LNM. Current research has demonstrated that patients with T1b esophageal cancers without LVI have a significantly higher survival rate up to 5 years higher those with LVI [32]. A larger cohort study revealed that LVI has a significant effect on the prognosis after resection for ESCC [33]. Our study shows that SEC patients with LVI have a poor OS $(\mathrm{HR}=$ 1.62, 95\% CI: $1.17-2.26, P=0.004, \mathrm{I}^{2}=0.0 \%$, and LVI significantly increases the risk of LNM in SEC (univariate: $\mathrm{OR}=5.26,95 \% \mathrm{CI}: 4-6.91, \quad P<0.0001$, $\mathrm{I}^{2}=30.2 \%$; multivariate: $\mathrm{OR}=5.7,95 \%$ CI:4.43-7.33,

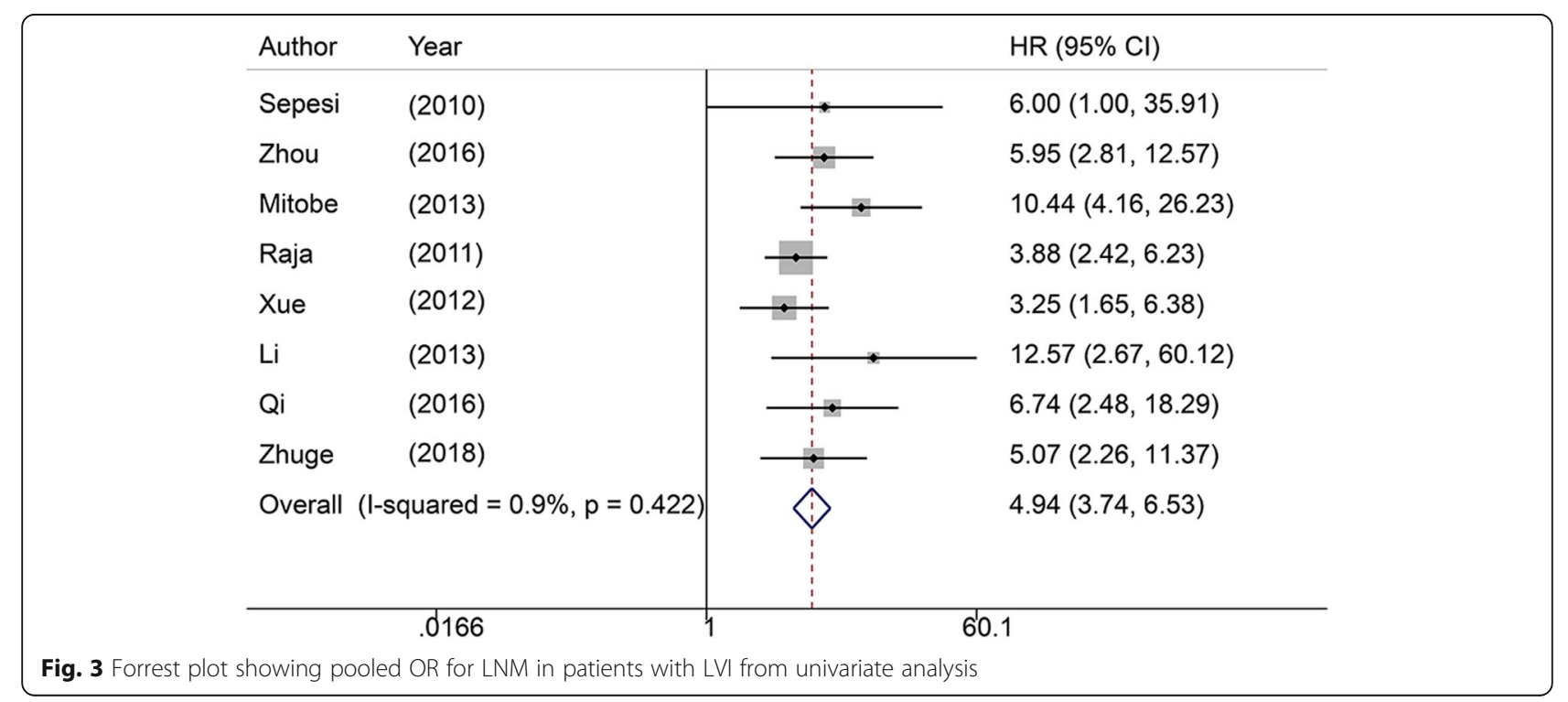




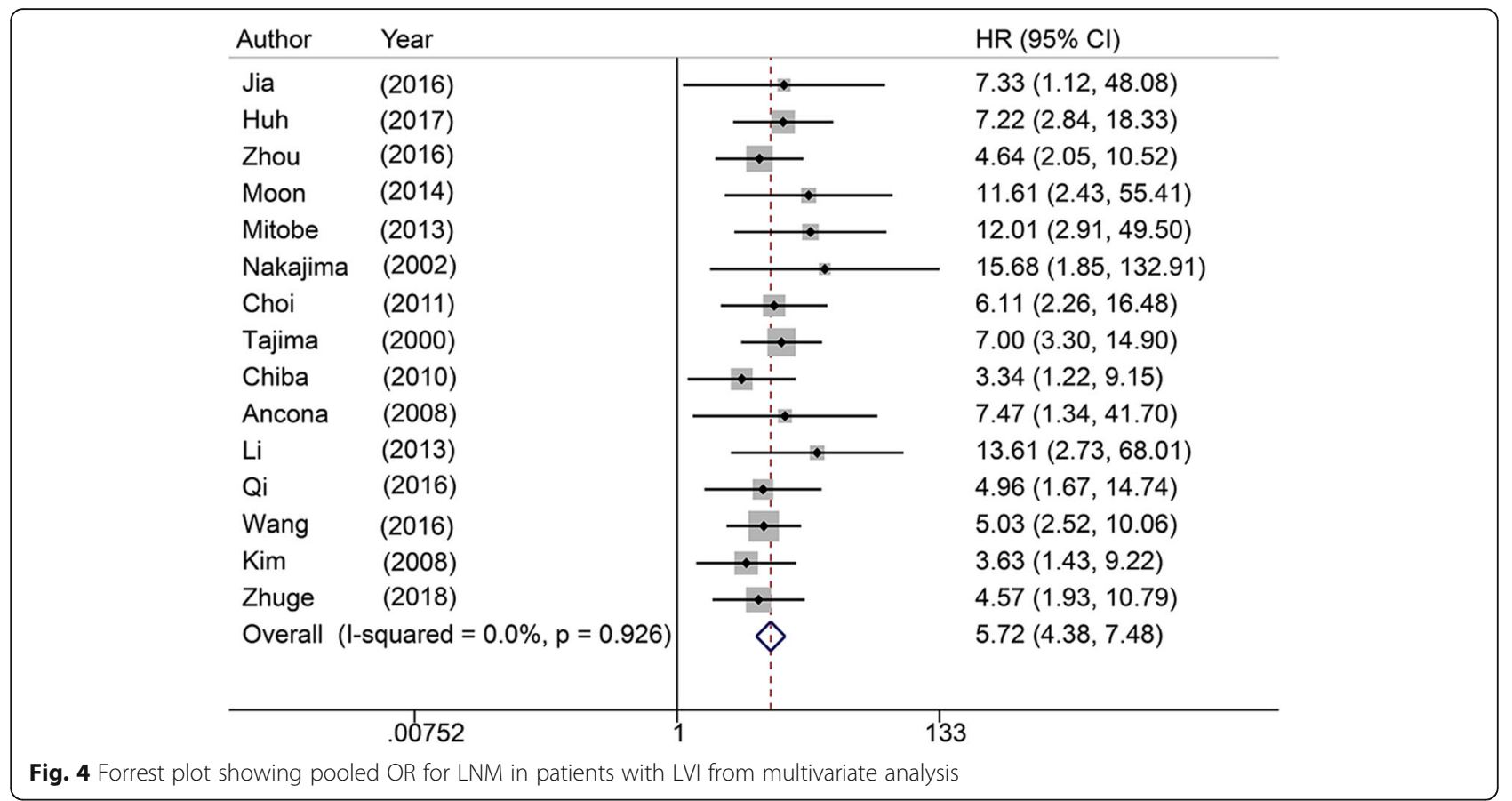

$\left.P<0.0001 ; \mathrm{I}^{2}=16 \%\right)$. Reports describing the relationship between LVI, LNM, and OS in SEC indicate that LVI raises the possibility of LNM, leading to a poor OS.

Esophagectomy and other non-surgical options including chemotherapy and radiotherapy are the mainstream treatments for esophageal cancer. However, endoscopic resection (ER) is the diagnostic and radical choice for the treatment of SEC with a low possibility of LNM. The Japan Esophageal Society published a guideline in 2014 recommending ER as the best treatment option for T0 and T1a lesions located within the limits of the mucosal layer and not associated with LNM. The treatment can still be applied for lesions that infiltrate the muscularis mucosae or the inner submucosa (T1b-SM1) but the risk of LNM exists for these cases. Hence, other classifications for superficial carcinomas (T1b-SM2 and T1b-SM3) should not be treated with endoscopy alone due to the high rates of metastasis [34]. ER can be classified as endoscopic mucosal resection (EMR) or endoscopic submucosal dissection (ESD). All visible neoplasms are removed by EMR for definitive histopathological staging. However, EMR is ineffective compared to ESD in terms of en bloc resection of large lesions. The largest lesion amenable to en bloc resection with the EMR device is approximately $15 \mathrm{~mm}[35,36]$ whereas en bloc resection can be achieved with ESD regardless of the size of neoplastic lesions [36]. Furthermore, several studies have reported that ESD has a higher $\mathrm{R} 0$ resection rate and a lower local recurrence rate compared to EMR. Therefore, ESD is considered the standard for ER treatment of ESCC [37-39]. Esophagectomy, the main surgical treatment for EC, was compared

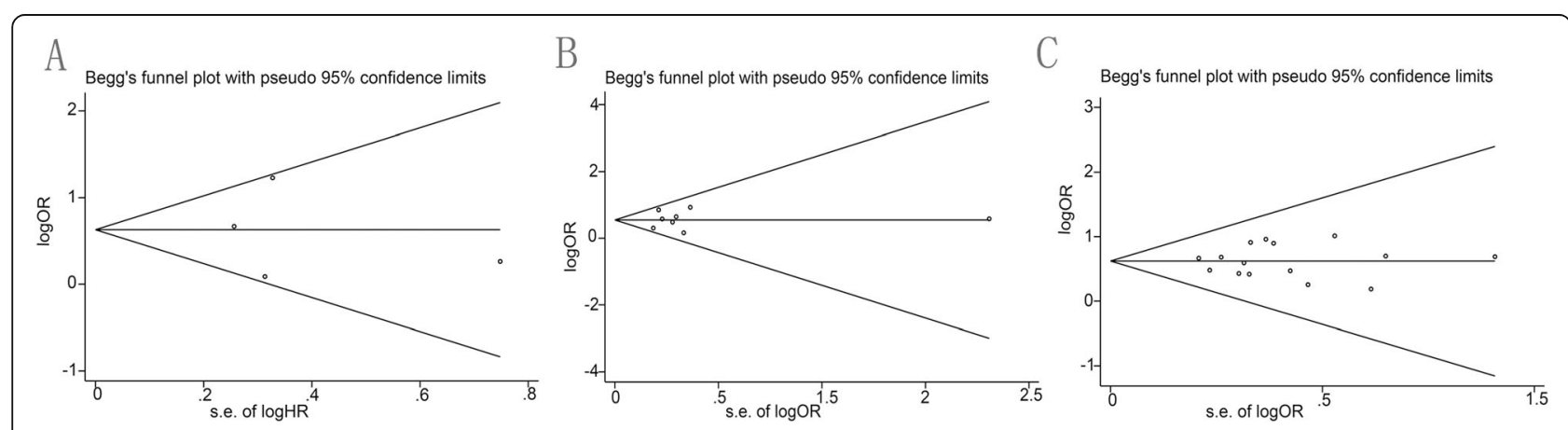

Fig. 5 The funnel plots of publication bias, a OS publication bias; $\mathbf{b}$ Bias of LNM on univariate; $\mathbf{c}$ Bias of LNM on multivariate 
with ER treatment and the results revealed that T1b lesions were managed endoscopically with no impact on survival [40-42]. Therefore, ER is preferable to surgery and also appears to be an optimal first-line treatment for early esophageal cancer.

This study does have some limitations. First, we used only studies published in English for our meta-analysis. Consequently, studies reporting negative results may have been overlooked. Next, the stages, treatment, staining method, and adjuvant therapy differed for each study. In addition, the heterogeneity of OS was medium. The subgroup analysis was unable to carry out due to limited studies. Few studies provided Kaplan-Meier curves and we calculated the HR and 95\% CI where necessary. Therefore, we strongly recommend interpreting the results with caution.

\section{Conclusions}

SEC patients with positive LVI indicated poor prognosis compared with patients without LVI. Therefore, the association between LVI and LNM in SEC patients was close.

\section{Abbreviations}

EC: Esophageal carcinoma; EJC: Esophagogastric junction cancer; EMR: Endoscopic mucosal resection; ER: Endoscopic resection; ESCC: Esophageal squamous cell carcinoma; ESD: Endoscopic submucosal dissection; HR: Hazard ratio; LNM: Lymph node metastasis; LVI: Lymphovascular invasion; NOS: Newcastle-Ottawa Scale; OS: Overall survival; SEC: Superficial esophageal carcinoma

\section{Acknowledgements}

None.

\section{Authors' contributions}

$J Y$ and $Z L$ contributed equally to this work. JY and DZ designed this project. $J Y, Z L, L L, Y L$ and $Y T$ did the data collection. JY, ZL, DZ and AW did the data analysis. JY and ZL wrote the manuscript. All authors read and approved the final manuscript.

\section{Funding}

Not applicable.

\section{Availability of data and materials}

The data sets used and analyzed during the current study available from the corresponding author on reasonable request.

Ethics approval and consent to participate

Not applicable.

\section{Consent for publication}

Not applicable.

\section{Competing interests}

The authors declare that they have no competing interests.

Received: 22 August 2019 Accepted: 18 February 2020

Published online: 04 March 2020

\section{References}

1. Japan Esophageal S. Japanese classification of Esophageal Cancer, 11th edition: part I. Esophagus. 2017;14(1):1-36.

2. Rice TW, Patil DT, Blackstone EH. 8th edition Ajcc/Uicc staging of cancers of the esophagus and Esophagogastric junction: application to clinical practice. Ann Cardiothorac Surg. 2017;6(2):119-30.
3. Huang Q, Luo K, Chen C, Wang G, Jin J, Kong M, et al. Identification and validation of Lymphovascular invasion as a prognostic and staging factor in node-negative Esophageal squamous cell carcinoma. J Thorac Oncol. 2016;11(4):583-92.

4. Karaman S, Detmar M. Mechanisms of lymphatic metastasis. J Clin Invest. 2014;124(3):922-8.

5. Sleeman JP, Thiele W. Tumor metastasis and the lymphatic vasculature. Int J Cancer. 2009;125(12):2747-56.

6. Stang A. Critical evaluation of the Newcastle-Ottawa scale for the assessment of the quality of nonrandomized studies in Meta-analyses. Eur J Epidemiol. 2010;25(9):603-5.

7. Leggett $C L$, Lewis JT, Wu TT, Schleck CD, Zinsmeister AR, Dunagan KT, et al. Clinical and Histologic Determinants of Mortality for Patients with Barrett's Esophagus-Related T1 Esophageal Adenocarcinoma. Clin Gastroenterol Hepatol. 2015;13(4):658-64 e1 3.

8. Yamashina T, Ishihara R, Nagai K, Matsuura N, Matsui F, Ito T, et al. Long-term outcome and metastatic risk after endoscopic resection of superficial Esophageal squamous cell carcinoma. Am J Gastroenterol. 2013;108(4):544-51.

9. Tanaka T, Matono S, Mori N, Shirouzu K, Fujita H. T1 squamous cell carcinoma of the esophagus: long-term outcomes and prognostic factors after Esophagectomy. Ann Surg Oncol. 2014;21(3):932-8.

10. Xue LY, Qin XM, Liu Y, Liang J, Lin H, Xue XM, et al. Clinicopathological parameters predicting recurrence of Pt1n0 Esophageal squamous cell carcinoma. World J Gastroenterol. 2018;24(45):5154-66.

11. Jia R, Luan Q, Wang J, Hou D, Zhao S. Analysis of predictors for lymph node metastasis in patients with superficial Esophageal carcinoma. Gastroenterol Res Pract. 2016;2016:3797615

12. Sepesi B, Watson TJ, Zhou D, Polomsky M, Litle VR, Jones CE, et al. Are endoscopic therapies appropriate for superficial submucosal Esophageal adenocarcinoma? An analysis of Esophagectomy specimens. J Am Coll Surg. 2010;210(4):418-27.

13. Huh $\mathrm{CW}$, Jung DH, Kim JH, Ma DW, Youn YH, Park H. Clinical implication of endoscopic gross appearance in superficial Esophageal squamous carcinoma: revisited. Surg Endosc. 2018;32(1):367-75.

14. Zhou Y, Du J, Li H, Luo J, Chen L, Wang W. Clinicopathologic analysis of lymph node status in superficial Esophageal squamous carcinoma. World J Surg Oncol. 2016;14(1):259.

15. Moon JY, Kim GH, Kim JH, Kim HH, Ryu KD, Park SO, et al. Clinicopathologic factors predicting lymph node metastasis in superficial Esophageal squamous cell carcinoma. Scand J Gastroenterol. 2014;49(5):589-94.

16. Mitobe J, Ikegami M, Urashima M, Takahashi H, Goda K, Tajiri H. Clinicopathological investigation of lymph node metastasis predictors in superficial Esophageal squamous cell carcinoma with a focus on evaluation of Lympho-vascular invasion. Scand J Gastroenterol. 2013;48(10):1173-82.

17. Nentwich MF, von Loga K, Reeh M, Uzunoglu FG, Marx A, Izbicki JR, et al. Depth of submucosal tumor infiltration and its relevance in lymphatic metastasis formation for T1b squamous cell and adenocarcinomas of the esophagus. J Gastrointest Surg. 2014;18(2):242-9 discussion 9

18. Raja S, Rice TW, Goldblum JR, Rybicki LA, Murthy SC, Mason DP, et al. Esophageal submucosa: the watershed for Esophageal Cancer. J Thorac Cardiovasc Surg. 2011;142(6):1403-11 e1.

19. Nakajima Y, Nagai K, Miyake S, Ohashi K, Kawano T, Iwai T. Evaluation of an Indicator for lymph node metastasis of Esophageal squamous cell carcinoma invading the submucosal layer. Jpn J Cancer Res. 2002;93(3):305-12.

20. Choi JY, Park YS, Jung HY, Ahn JY, Kim MY, Lee JH, et al. Feasibility of Endoscopic Resection in Superficial Esophageal Squamous Carcinoma. Gastrointest Endosc. 2011;73(5):881-9 9 e1-2.

21. Tajima $Y$, Nakanishi $Y$, Ochiai $A$, Tachimori $Y$, Kato $H$, Watanabe $H$, et al. Histopathologic findings predicting lymph node metastasis and prognosis of patients with superficial Esophageal carcinoma: analysis of 240 surgically resected tumors. Cancer. 2000;88(6):1285-93.

22. Chiba T, Kawachi H, Kawano T, Kumagai J, Kitagaki K, Sekine M, et al. Independent histological risk factors for lymph node metastasis of superficial Esophageal squamous cell carcinoma; implication of Claudin-5 immunohistochemistry for expanding the indications of endoscopic resection. Dis Esophagus. 2010;23(5):398-407.

23. Xue L, Ren L, Zou S, Shan L, Liu X, Xie Y, et al. Parameters predicting lymph node metastasis in patients with superficial Esophageal squamous cell carcinoma. Mod Pathol. 2012;25(10):1364-77.

24. Ancona E, Rampado S, Cassaro M, Battaglia G, Ruol A, Castoro C, et al. Prediction of lymph node status in superficial Esophageal carcinoma. Ann Surg Oncol. 2008;15(11):3278-88. 
25. Li B, Chen H, Xiang J, Zhang Y, Kong Y, Garfield DH, et al. Prevalence of lymph node metastases in superficial Esophageal squamous cell carcinoma. J Thorac Cardiovasc Surg. 2013;146(5):1198-203.

26. Qi X, Li M, Zhao S, Luo J, Shao Y, Zhang Z, et al. Prevalence of metastasis in T1b Esophageal squamous cell carcinoma: a retrospective analysis of 258 Chinese patients. J Thorac Dis. 2016;8(5):966-76.

27. Wang S, Chen X, Fan J, Lu L. Prognostic significance of Lymphovascular invasion for thoracic Esophageal squamous cell carcinoma. Ann Surg Oncol. 2016;23(12):4101-9.

28. Kim DU, Lee JH, Min B-H, Shim SG, Chang DK, Kim Y-H, et al. Risk factors of lymph node metastasis in T1 Esophageal squamous cell carcinoma. J Gastroenterol Hepatol. 2008;23(4):619-25.

29. Zhuge L, Wang S, Xie J, Huang B, Zheng D, Zheng S, et al. A model based on endoscopic morphology of submucosal Esophageal squamous cell carcinoma for determining risk of metastasis on lymph nodes. J Thorac Dis. 2018;10(12):6846-53.

30. Barret M, Prat F. Diagnosis and treatment of superficial Esophageal Cancer. Ann Gastroenterol. 2018;31(3):256-65.

31. Dunbar KB, Spechler SJ. The risk of lymph-node metastases in patients with high-grade dysplasia or Intramucosal carcinoma in Barrett's esophagus: a systematic review. Am J Gastroenterol. 2012;107(6):850-62 quiz 63.

32. Cen P, Hofstetter WL, Correa AM, Wu TT, Lee JH, Ross WA, et al. Lymphovascular invasion as a tool to further subclassify T1b Esophageal adenocarcinoma. Cancer. 2008:112(5):1020-7.

33. Yang YS, Wang WP, Chen LQ. The effect of interaction between Lymphovascular invasion and lymph node metastasis. Surgery. 2017:161(5):1466-7.

34. Kuwano H, Nishimura Y, Oyama T, Kato H, Kitagawa Y, Kusano M, et al. Guidelines for Diagnosis and Treatment of Carcinoma of the Esophagus April 2012 Edited by the Japan Esophageal society. Esophagus. 2015;12:1-30.

35. Othman MO, Wallace MB. Endoscopic mucosal resection (Emr) and endoscopic submucosal dissection (Esd) in 2011, a Western perspective. Clin Res Hepatol Gastroenterol. 2011;35(4):288-94.

36. Yamamoto H, Kawata H, Sunada K, Sasaki A, Nakazawa K, Miyata T, et al. Successful en-bloc resection of large superficial tumors in the stomach and Colon using sodium hyaluronate and small-caliber-tip transparent Hood. Endoscopy. 2003;35(8):690-4.

37. Pimentel-Nunes P, Dinis-Ribeiro M, Ponchon T, Repici A, Vieth M, De Ceglie A, et al. Endoscopic submucosal dissection: European Society of Gastrointestinal Endoscopy (Esge) guideline. Endoscopy. 2015:47(9):829-54.

38. Takahashi H, Arimura Y, Masao H, Okahara S, Tanuma T, Kodaira J, et al. Endoscopic Submucosal Dissection Is Superior to Conventional Endoscopic Resection as a Curative Treatment for Early Squamous Cell Carcinoma of the Esophagus (with Video). Gastrointest Endosc. 2010;72(2):255-64 64 e1-2.

39. Cao Y, Liao C, Tan A, Gao Y, Mo Z, Gao F. Meta-analysis of endoscopic submucosal dissection versus endoscopic mucosal resection for tumors of the gastrointestinal tract. Endoscopy. 2009;41(9):751-7.

40. Pech O, Bollschweiler E, Manner H, Leers J, Ell C, Holscher AH. Comparison between endoscopic and surgical resection of mucosal Esophageal adenocarcinoma in Barrett's esophagus at two high-volume centers. Ann Surg. 2011;254(1):67-72.

41. Das A, Singh V, Fleischer DE, Sharma VK. A comparison of endoscopic treatment and surgery in early Esophageal Cancer: an analysis of surveillance epidemiology and end results data. Am J Gastroenterol. 2008; 103(6):1340-5.

42. Prasad GA, Wu TT, Wigle DA, Buttar NS, Wongkeesong LM, Dunagan KT, et al. Endoscopic and surgical treatment of mucosal (T1a) Esophageal adenocarcinoma in Barrett's esophagus. Gastroenterology. 2009;137(3):815-23.

\section{Publisher's Note}

Springer Nature remains neutral with regard to jurisdictional claims in published maps and institutional affiliations.

Ready to submit your research? Choose BMC and benefit from:

- fast, convenient online submission

- thorough peer review by experienced researchers in your field

- rapid publication on acceptance

- support for research data, including large and complex data types

- gold Open Access which fosters wider collaboration and increased citations

- maximum visibility for your research: over $100 \mathrm{M}$ website views per year

At $\mathrm{BMC}$, research is always in progress.

Learn more biomedcentral.com/submissions 